\title{
To have in order to do: Exploring the effects of consuming experiential products on well-being
}

\author{
Darwin A. Guevarra ${ }^{\text {a }}$, Ryan T. Howell ${ }^{\text {b,* }}$ \\ ${ }^{\text {a }}$ Department of Psychology, University of Michigan, Ann Arbor, MI, USA \\ ${ }^{\mathrm{b}}$ Department of Psychology, San Francisco State University, San Francisco, CA, USA
}

15 October 2012; 24 June 2014; 26 June 2014

Available online 2 July 2014

\begin{abstract}
The experience recommendation - if you want to be happier, buy life experiences instead of material items - is supported in empirical research. However, this evidence is primarily based on the dichotomous comparison of material items and life experiences. The goal of this article is to examine the effects of consuming experiential products - purchases that fall between material items and life experiences - on well-being. Study 1 and Study 2 demonstrate that experiential products provide similar levels of well-being compared to life experiences and more well-being than material items. Study 3 replicates this finding for purchases that turn out well. In addition, Study 3 shows experiential products, when compared to life experiences, lead to more feelings of competence but less feelings of relatedness, which explains why these two purchases result in similar levels of well-being. We discuss why experiential products and life experiences lead to psychological need satisfaction and how our results support the Positive-Activity Model, Self-Determination Theory, and Holbrook and Hirschman's hedonic consumption framework.
\end{abstract}

(C) 2014 Society for Consumer Psychology. Published by Elsevier Inc. All rights reserved.

Keywords: Experiential products; Life experiences; Material items; Well-being

\section{Introduction}

The improvement of well-being is associated with a host of individual and societal benefits (e.g., better health, longer life, and higher income; see Lyubomirsky, King, \& Diener, 2005). As a result, there has been a proliferation of research on activities that increase happiness (Boehm, Lyubomirsky, \& Sheldon, 2011). Some successful strategies include counting one's blessings (Emmons \& McCullough, 2003), expressing gratitude (Lyubomirsky, Sheldon, \& Schkade, 2005), and meditating (Fredrickson, Cohn, Coffey, Pek, \& Finkel, 2008). A number of different consumer activities have also been examined to determine which consumer behaviors increase happiness. Hedonic consumption - those purchases that focus

\footnotetext{
* Corresponding author at: Quantitative Psychologist, San Francisco State University, 1600 Holloway Avenue, San Francisco, CA 94132.

E-mail address: rhowell@sfsu.edu (R.T. Howell).
}

on enjoyment, fun, and pleasure - has been shown to improve happiness (Alba \& Williams, 2012; Bigné, Mattila, \& Andreu, 2008; Burroughs \& Rindfleisch, 2002; Dhar \& Wertenbroch, 2000; Okada, 2005; Zhong \& Mitchell, 2010). However, hedonic purchases provide different levels of well-being depending on whether the purchases are material items (i.e., tangible objects that are possessions) or life experiences (i.e., events that one lives through; see Carter \& Gilovich, 2014, for a review). Overall, the consumption of life experiences, when compared to material items, provides greater well-being (see Caprariello \& Reis, 2013; Carter \& Gilovich, 2010, 2012; Howell \& Hill, 2009; Van Boven \& Gilovich, 2003). These studies provide support for the experience recommendation--if you want to be happier, buy life experiences instead of material items (Nicolao, Irwin, \& Goodman, 2009).

However, most of the studies testing the experience recommendation focus on comparing the well-being provided by material items and life experiences. Although previous 
research has conceptualized material items and life experiences as anchors on a material-experiential continuum (Carter \& Gilovich, 2014; Nicolao et al., 2009; Van Boven, 2005), purchases that fall between these two anchors tend to be considered "ambiguous" and are often overlooked (see Carter \& Gilovich, 2014; Howell \& Guevarra, 2013). For example, purchases such as electronic devices, musical instruments, and sports equipment are often difficult to categorize as material items (i.e., purchases made in order "to have") or life experiences (i.e., purchases made in order "to do") because they share defining features of both (Hellén \& Gummerus, 2013; Lovelock \& Gummesson, 2004). These "material possessions that afford new life experiences," or experiential products, may be a distinct category as they are neither terminal material items nor ephemeral life experiences (see Van Boven \& Gilovich, 2003, p. 1201). More importantly, knowing the effect of these purchases that people make to have in order to do on well-being is critical to understanding the relationship between consumer activities and happiness as well as the accuracy and boundaries of the experience recommendation (Dunn, Gilbert, \& Wilson, 2011; Lynch, Alba, Krishna, Morwitz, \& Gürhan-Canli, 2012). Therefore, the goal of this article is to examine the effects of consuming experiential products on well-being.

\section{Theoretical framework}

\section{The experiential advantage}

Numerous studies demonstrate that buying and consuming life experiences, instead of material items, lead to greater well-being (Caprariello \& Reis, 2013; Dunn et al., 2011; Howell \& Hill, 2009; Nicolao et al., 2009; Pchelin \& Howell, 2014; Van Boven \& Gilovich, 2003). Why is this the case? Lyubomirsky and Layous (2013) posits that any activity can make people happier if it leads to positive emotions, thoughts, and behaviors, and/or if it satisfies the psychological needs of autonomy, competence, and relatedness (also see Deci \& Ryan, 2012). Autonomy is satisfied through engaging in behaviors that express one's true identity and facilitate a feeling of being in charge of one's own actions (Ryan \& Deci, 2000). Competence is satisfied through engaging in activities that utilize one's skills and abilities (Deci, 1975). Relatedness is satisfied by engaging in activities that lead to a sense of belonging with others (Baumeister \& Leary, 1995). Indeed, past research has theorized and demonstrated that one reason consuming life experiences, instead of material items, leads to greater well-being is through the satisfaction of relatedness and identity (i.e., a proxy for autonomy in the material-experiential buying literature) needs (Carter \& Gilovich, 2012; Howell \& Hill, 2009; Howell \& Howell, 2008). For example, life experiences, compared to material items, are more likely to be shared with others and lead to greater feelings of relatedness (Caprariello \& Reis, 2013; Raghunathan \& Corfman, 2006). In fact, some life experiences, such as whitewater rafting and gambling, are purchased with the goal to belong to a community and feel connected with others (Arnould \& Price,
1993; Cotte, 1997). Furthermore, life experiences, compared to material items, better represent one's true self (Carter \& Gilovich, 2012), meaning that people tend to define themselves more in terms of their life experiences than their material items. In fact, certain life experiences, such as skydiving, are made with the intention to help construct one's identity and express one's self (Celsi, Rose, \& Leigh, 1993).

Importantly, as predicted by the Positive-Activity Model, these results align with the tenants of Self-Determination Theory which theorizes that optimal well-being occurs when psychological needs are satisfied (Deci \& Ryan, 2012; Ryan \& Deci, 2000). Consistent with the Positive-Activity Model, the satisfaction of psychological needs (e.g., fulfilling the need for relatedness by sharing life experiences with others) are some of the most consistently supported mediators between activities and happiness (Ryan \& Deci, 2000, 2001). Furthermore, the Positive-Activity Model complements Holbrook and Hirschman (1982), which suggests that hedonic purchases may increase well-being because they engage the consumer through multiple sensory modalities, facilitate fantasy-like and positive reinterpretations of consumer experiences, and produce positive emotional experiences. Additionally, marketing research has identified various consumer experience dimensions which parallel the psychological needs of autonomy, competence, and relatedness through the consumer experience dimensions of acting (Schmitt, 2010), pragmatic/thinking (Gentile, Spiller, \& Noci, 2007), and relations (Schmitt \& Zarantonello, 2013), respectively. Therefore, consistent with the psychological and consumer experience literature, the Positive-Activity Model, with a focus on psychological needs as mediators, provides a helpful framework to develop hypotheses regarding the effects of consuming experiential products on well-being.

\section{To have in order to do: Experiential products}

Although there is support that life experiences make people happier and are a better economic investment than material items, most studies have restricted the comparison to these two categories (see Carter \& Gilovich, 2012, 2014; Howell \& Guevarra, 2013). This purchase dichotomy seems reasonable as people can easily recognize this distinction, reliably classify their purchases as either material or experiential, and place their purchases on a material-experiential continuum scale (see Carter \& Gilovich, 2014, for a review and justification). However, in many studies, researchers ensure that participants only recall material items or life experiences by highlighting that material items are purchases that people make in order "to have" while life experiences are purchases that people make in order "to do" (Van Boven \& Gilovich, 2003). Further, when studies ask participants to rate their purchases on a material-experiential continuum, they tend to examine linear models (Nicolao et al., 2009 [Study 2]) or create two categories (i.e., material and experiential) from the material-experiential rating scale (Caprariello \& Reis, 2013). Unfortunately, by testing linear models or focusing on material items and life experiences, we know very little about the well-being effects of 
purchases that people make "to have in order to do." This is detrimental to understanding the connection between expenditures and happiness because many purchases embody qualities of both material items and life experiences (Hellén \& Gummerus, 2013; Lovelock \& Gummesson, 2004). Further, the experience recommendation is more nuanced than originally proposed as there are specific purchase (Bhattacharjee \& Mogilner, 2014; Nicolao et al., 2009) and consumer characteristics (Zhang, Howell, Caprariello, \& Guevarra, 2014) that moderate the experiential advantage. Thus, our solution to this gap in the literature is simple - directly examine the effects of consuming experiential products on well-being.

Our examination of experiential products must answer one fundamental question: Do experiential products lead to well-being that is more similar to that derived from material items, from life experiences, or something in between? On one hand, experiential products share the defining features of material items as they are tangible objects that are obtained and kept in one's possession (Van Boven \& Gilovich, 2003). Therefore, much like material items, the tangible nature of experiential products may lead to less psychological need satisfaction (Howell \& Hill, 2009). Moreover, people might find it easier to compare experiential products, relative to life experiences, which could make them more susceptible to negative comparisons (Carter \& Gilovich, 2010; Howell \& Hill, 2009; Martín-Ruiz \& Rondán-Cataluña, 2008). Because experiential products may lead to less psychological need satisfaction and/or more deleterious social comparisons, they could yield less well-being than life experiences. On the other hand, experiential products are vehicles for life experiences because they create or enhance events that people live through (Van Boven \& Gilovich, 2003). Therefore, the intangible component of experiential products may facilitate the satisfaction of people's psychological needs, at least compared to material items. It is because of this hybrid nature of experiential products, possessing both tangible and intangible qualities, that the material-experiential buying and marketing literatures appear to support three rival hypotheses (see $\mathrm{H} 1, \mathrm{H} 2$, and $\mathrm{H} 3$ below). We review the material-experiential buying and marketing literatures to provide support for each rival hypothesis, and in addition, to support a fourth hypothesis (H4) on what explains this effect between purchase type and well-being.

\section{The rationale for $\mathrm{H} 1$}

Experiential products and material items are both tangible objects that are obtained and kept in one's possession (Van Boven \& Gilovich, 2003). Thus, because of their shared tangibility, material items and experiential products could provide similar levels of well-being. For example, the tangibility of experiential products may promote extrinsic concerns for the consumer such as social comparisons or comparison with better options. We know that extrinsic concerns directly undermine the well-being provided by material items (Carmon, Wertenbroch, \& Zeelenberg, 2003; Ferraro, Escalas, \& Bettman, 2011; Hsee, Yang, Li, \& Shen,
2009; Rosenzweig \& Gilovich, 2012; Zhang, Howell, \& Caprariello, 2013; Zhang \& Markman, 2001) in part because extrinsic motivations reduce the satisfaction of psychological needs (Deci \& Ryan, 2012). Therefore, extrinsic concerns might also directly undermine the well-being provided by experiential products. Moreover, like material items, experiential products eventually deteriorate and need to be upgraded, maintained, or stored (Hellén \& Gummerus, 2013; Moeller \& Wittkowski, 2010), all of which may detract from the well-being they provide. Thus, if it is the tangible nature of experiential products that has the biggest effect on well-being, then it is reasonable to argue that experiential products will provide similar levels of well-being compared to material items and less well-being than life experiences.

H1. Experiential products will provide similar levels of well-being compared to material items and less than life experiences.

\section{The rationale for $\mathrm{H} 2$}

Experiential products, unlike material items, enrich and create their own life experiences (Van Boven \& Gilovich, 2003); for example, consuming video games facilitates multisensory, fantasy-like, and interactive experiences. Moreover, the use of goods that render a service tend to be consumed more as life experiences and less as material items (Grönroos, 2008). As experiential products increase in their intangibility, consumers become more likely to reconstruct their evaluations of these purchases as life experiences (Braun, 1999), resulting in similar and rosier recollections (Van Boven \& Gilovich, 2003). Therefore, it is possible that the intangible nature of experiential products has the biggest effect on well-being and provides similar levels of well-being as life experiences. Experiential products also appear to be designed to increase psychological needs. For example, consuming experiential products such as video games, musical instruments, and sporting goods often requires people to utilize their skills and abilities, and this active engagement during consumption should lead to greater competence satisfaction (Alba \& Williams, 2012; Sääksjärvi \& Hellén, 2013). Moreover, people buy some material items to be used with others (e.g., social material purchases; see Caprariello \& Reis, 2013). Assuming that social material purchases are more likely to be experiential products, then they should better satisfy the need for relatedness. In sum, the increased need satisfaction from experiential products, relative to material items, should result in similar levels of well-being compared to life experiences and more than that derived from material items.

H2. Experiential products will provide similar levels of well-being compared to life experiences and more than material items.

\section{The rationale for $\mathrm{H3}$}

The effect of consumption on well-being is multiply determined (Carter \& Gilovich, 2012; Howell \& Hill, 2009). 
Therefore, because experiential products share characteristics of both material items and life experiences in having both tangible and intangible components, then it is possible that these characteristics both add and subtract from the effects they have on well-being. Indeed, Andrade and Cohen (2007) demonstrated that individuals can experience both negative and positive outcomes during consumption. It is possible then that experiential products may satisfy the need for competence, which should increase well-being, and at the same time, concerns over extrinsic factors may detract from well-being. If this is the case, then experiential products should provide more well-being than material items but less than life experiences. This hypothesis is also supported by linear models regarding the relationship between how material or experiential a purchase is on a material-experiential rating scale and how much happiness a purchase provides (see Nicolao et al., 2009 [Study 2]).

H3. Experiential products will provide more well-being than material items but less than life experiences.

\section{The rationale for $\mathrm{H} 4$}

Based on previous findings from the material-experiential buying literature discussed above, as well as the PositiveActivity Model, we expect differences in well-being, regardless of which rival hypothesis is supported, to be explained by differences in the satisfaction of psychological needs. To reiterate, previous research has shown that the relationship between purchase types and happiness is mediated by satisfying the psychological needs of relatedness and identity (Carter \& Gilovich, 2012; Howell \& Hill, 2009). This leads to our final hypothesis:

H4. The impact of purchase types (i.e., material items, experiential products, and life experiences) on well-being will be explained by the satisfaction of psychological needs.

\section{Overview of the research}

The primary goal of these studies is to examine the differences in well-being and psychological need satisfaction that result from three purchase types: material items, experiential products, and life experiences. We test the support for our rival hypotheses across three studies. Study 1 uses a quasi-experimental design to demonstrate that people recognize the experiential product category and provide preliminary support for H2: Experiential products will provide similar levels of well-being compared to life experiences and more than material items. Study 2 experimentally replicates the support for H2. Study 3 adds a product outcome factor (i.e., did the purchase turn out well or not) to test $\mathrm{H} 2$ and examines the support for H4: The impact of purchase types on well-being will be explained by the satisfaction of psychological needs. Study 3 supports $\mathrm{H} 2$ and $\mathrm{H} 4$ by showing that (a) experiential products, compared to material items, lead to more psychological need satisfaction (resulting in greater well-being), and (b) experiential products, compared to life experiences, lead to increased competence as well as decreased feelings of relatedness, which explains why these two purchases result in similar levels of well-being.

In order to examine the differences in well-being and psychological need satisfaction provided by the three purchase types, we used the following analytic plan. First, we examined the mean differences across the three purchase types (i.e., material items, experiential products, and life experiences) for each dependent variable by first conducting an omnibus ANCOVA and reporting the results of these tests as well as the effect of two covariates: price and recency (i.e., how long ago the purchase took place). Second, for each significant omnibus test, we conducted three pairwise $t$-tests on the covariate adjusted means in order to compare: (a) life experiences vs. material items (the traditional tests of the experience recommendation), (b) experiential products vs. material items, and (c) experiential products vs. life experiences. Because we examined multiple comparisons, we used a Sidak adjustment on the $p$-value to reduce the likelihood of Type I error. In Tables 2 and 3, significant differences between purchase types are indicated by different superscripts next to the corresponding mean. To examine the support for $\mathrm{H} 4$ in Study 3, we used the Hayes PROCESS macro to conduct regression analyses aimed at understanding the significant indirect paths (Model 4; see Hayes, 2013).

\section{Study 1: Exploring the effects of experiential products on well-being}

As has been typical in previous material-experiential buying studies, the first goal of Study 1 was to establish that experiential products are easily recalled and widely recognized as a purchase type (Van Boven \& Gilovich, 2003). In order to do this, each participant self-generated a recent purchase that they "thought would make [them] happier" and self-categorized that purchase into one of three categories: a material item, an experiential product, or a life experience. The second goal of Study 1 was to determine which of our three rival hypotheses was supported.

\section{Method}

\section{Participants}

Three hundred and seventy participants $\left(M_{\text {age }}=32.07\right.$ years, $S D=15.71$ years; $65.7 \%$ female; $54.3 \%$ Caucasian) completed an online study on Amazon's Mechanical Turk in exchange for $\$ 0.50$.

\section{Materials and procedures}

Participants were instructed to "Think about a recent time when you used your money to pay for/buy something you thought would make you happier. You could have used your money in any way, as long as when you spent your money your goal was to increase the joy and happiness in your life." After briefly writing, participants selected the category which best described their purchase: (1) a material good or product (e.g., jewelry, clothing), (2) a material good that provides an 
experience (e.g., book, guitar), (3) a life experience (e.g., eating out, going to a concert, traveling). Then they rated the hedonic well-being and subjective economic value (see scales below) of their purchase. Participants reported how much money they spent on their purchase $(M=\$ 497.71, S D=\$ 1,086.72)$ and when they last used their material item or how long ago they consumed their life experience $(49.7 \%$ in the last week). Finally, participants completed well-being and financial security measures to determine if those who self-selected to think about an experiential product differed from those who self-selected to think about a material item or life experience.

\section{Hedonic well-being}

To measure hedonic well-being, participants answered the question "how much does this purchase contribute to your happiness today?" from 1 (not at all) to 7 (very much). Higher scores indicated more hedonic well-being $(M=5.16, S D=1.42)$.

\section{Subjective economic value}

We asked respondents to "evaluate the wisdom of their purchase from an economic standpoint" (Van Boven \& Gilovich, 2003, p. 1194) using two economic value questions asked in previous research (see Pchelin \& Howell, 2014). To measure subjective economic value, participants answered the following two questions: "To what extent do you think the money spent on this purchase would have been better spent on something else - some other type of purchase that would have made you happier?" from 1 (not at all) to 7 (very much) and "To what extent do you feel this purchase was a good use of your money?" from 1 (a poor use of my money) to 7 (a great use of my money). These two items were negatively correlated $(r$ [386] $=-.46, p<.001)$ and were averaged after the first item was reverse coded. Higher scores indicated more subjective economic value $(M=5.16, S D=1.42 ; \alpha=.63)$.

\section{Results}

\section{Preliminary analyses}

In Study 1, participants self-generated a non-trivial number of experiential products $(25.7 \%)$ as well as material items $(40.5 \%)$ and life experiences (33.8\%). In Table 1, we report the percent of purchases within each category (e.g., clothing, electronic devices, dining out) separated by purchase type (material item, experiential product, and life experience) across all three studies.

There were no differences in trait levels of happiness $(F[2,367]=.032, p=.97)$ nor financial security $(F[2,367]=$ $1.50, p=.27)$ among participants. There were, however, significant differences in the price $(F[2,367]=9.83, p<.001)$ and recency $(F[2,367]=66.68, p<.001)$ across the three purchase types. After applying a Sidak adjustment, the first set of pairwise $t$-tests demonstrated that participants spent significantly more on life experiences than on material items $(t[367]=4.40$, $p<.001)$ and experiential products $(t[367]=2.64, p=.02)$; however, there was no significant difference in the cost of material items compared to experiential products $(t[367]=1.32$, $p=.46)$. The second set of pairwise $t$-tests demonstrated that
Table 1

Percentage of material items, experiential products, and life experiences combining all three studies.

\begin{tabular}{llll}
\hline & \multicolumn{3}{c}{ Purchase type } \\
\cline { 2 - 4 } Purchase category & $\begin{array}{l}\text { Material } \\
\text { item }\end{array}$ & $\begin{array}{l}\text { Experiential } \\
\text { product }\end{array}$ & $\begin{array}{l}\text { Life } \\
\text { experience }\end{array}$ \\
\hline Clothing/jewelry/accessories & $\mathbf{2 3 7}(\mathbf{6 2} \%)$ & $\mathbf{3 6}(\mathbf{1 1} \%)$ & $11(3 \%)$ \\
Electronic devices/video games & $\mathbf{9 3}(\mathbf{2 4} \%)$ & $\mathbf{1 7 5}(\mathbf{5 5} \%)$ & $19(6 \%)$ \\
Sporting goods & $9(2 \%)$ & $\mathbf{4 1}(\mathbf{1 3} \%)$ & $2(.6 \%)$ \\
Musical instruments & - & $17(5 \%)$ & $3(1 \%)$ \\
Dining experience & - & $3(1 \%)$ & $\mathbf{8 5}(\mathbf{2 6} \%)$ \\
Fees and admissions & $1(.2 \%)$ & $6(2 \%)$ & $\mathbf{8 9}(\mathbf{2 7} \%)$ \\
Travel/outdoor activities & - & $7(2 \%)$ & $\mathbf{1 1 2}(\mathbf{3 4} \%)$ \\
Beauty products & $12(3 \%)$ & $3(1 \%)$ & - \\
Home décor & $19(5 \%)$ & $12(4 \%)$ & $2(.6 \%)$ \\
Self-pampering & $2(.5 \%)$ & $4(1 \%)$ & $9(3 \%)$ \\
Books/CDs/DVDs & $8(2 \%)$ & $16(5 \%)$ & $1(.3 \%)$ \\
\hline
\end{tabular}

Note. Percentages in parentheses are the purchase category frequency for that particular purchase type. A dash indicates no purchase category items for that purchase type. The boldface figures indicate the top three purchase types for that specific purchase category.

material items and experiential products were more recently purchased than life experiences $(t[367]=10.10, p<.001$ and $t$ $[367]=9.82, p<.001$, respectively); however, there was no difference in the recency of material items and experiential products $(t[367]=.84, p=.78)$. Therefore, following our established analytic plan (see above), we conducted two one-way ANCOVAs (purchase type: material item vs. experiential product vs. life experience), controlling for both purchase price and recency, to determine if the three purchase types differed in well-being (i.e., hedonic well-being or subjective economic value). For all pairwise $t$-tests we applied a Sidak adjustment (see Table 2 for significant differences in the covariate adjusted means).

\section{Well-being differences across the three purchase types}

The first one-way ANCOVA, controlling for price $(F[1,365]=51.60, p<.001)$ and recency $(F[1,365]=.10$, $p=.75)$, demonstrated that there were significant differences on hedonic well-being $(F[2,365]=4.67, p=.01)$ and provided support for H2. Specifically, the three pairwise $t$-tests showed that (a) life experiences provided more hedonic well-being than material items $(t[367]=2.46, p=.04, d=.34)$, (b) experiential products provided more hedonic well-being than material items $(t[367]=2.57, p=.03, d=.34)$, and (c) experiential products and life experiences provided similar levels of hedonic well-being $(t[367]=.007, p=.99$, $d=.001)$. A second one-way ANCOVA, controlling for price $F[1,365]=.48, p=.49)$ and recency $(F[1,365]=.39, p=.53)$, demonstrated that there were significant differences on subjective economic value $(F[2,365]=6.39, p=.002)$ and provided support for H2. Specifically, the three pairwise $t$-tests showed that (a) life experiences provided more subjective economic value than material items $(t[367]=2.96, p=.01, d=.41)$, (b) experiential products provided more subjective economic value than material items $(t[367]=3.09, p=.01, d=.41)$, and 
Table 2

Study 1 and Study 2: Covariate adjusted means and standard errors for hedonic well-being and subjective economic value across three purchase types.

\begin{tabular}{|c|c|c|c|c|c|c|c|c|c|}
\hline \multirow[b]{3}{*}{ Purchase outcomes } & \multicolumn{9}{|c|}{ Purchase type } \\
\hline & \multicolumn{3}{|c|}{ Material item } & \multicolumn{3}{|c|}{$\begin{array}{l}\text { Experiential } \\
\text { product }\end{array}$} & \multicolumn{3}{|c|}{$\begin{array}{l}\text { Life } \\
\text { experience }\end{array}$} \\
\hline & $N$ & $M$ & $S E$ & $N$ & $M$ & $S E$ & $N$ & $M$ & $S E$ \\
\hline \multicolumn{10}{|l|}{ Study 1} \\
\hline $\begin{array}{l}\text { Hedonic well-being } \\
\qquad(F[2,365]=4.67, p=.010)\end{array}$ & 150 & $4.30^{\mathrm{b}}$ & .15 & 95 & $4.90^{\mathrm{a}}$ & .19 & 125 & $4.90^{\mathrm{a}}$ & .18 \\
\hline $\begin{array}{l}\text { Subjective economic value } \\
\qquad(F[2,365]=6.39, p=.002)\end{array}$ & 150 & $4.81^{b}$ & .14 & 95 & $5.47^{\mathrm{a}}$ & .17 & 125 & $5.47^{\mathrm{a}}$ & .16 \\
\hline \multicolumn{10}{|l|}{ Study 2} \\
\hline $\begin{array}{l}\text { Hedonic well-being } \\
\qquad(F[2,141]=13.27, p<.001)\end{array}$ & 52 & $4.21^{b}$ & .18 & 43 & $5.59^{\mathrm{a}}$ & .20 & 51 & $5.06^{\mathrm{a}}$ & .18 \\
\hline $\begin{array}{l}\text { Subjective economic value } \\
\qquad(F[2,141]=5.96, p=.003)\end{array}$ & 52 & $5.33^{b}$ & .17 & 43 & $6.10^{\mathrm{a}}$ & .19 & 51 & $5.88^{\mathrm{a}}$ & .17 \\
\hline
\end{tabular}

Note. For both hedonic well-being and subjective economic value we report omnibus results as well as which pair of covariate adjusted means differ within each study. Superscripts denote significant differences between purchase types at $p \leq .05$ after applying a Sidak adjustment. In Study 1, hedonic well-being is measured with one item while economic value is measured with two items. In Study 2, both constructs are measured with three items. In both studies, mean differences are adjusted for differences in price and recency of the purchase.

(c) experiential products and life experiences provided similar levels of subjective economic value $(t[367]=.004, p=.99, d=$ .0006).

\section{Brief discussion}

Study 1 has three notable findings. First, we confirmed that people can easily recognize experiential products and classify their purchases as either material items, experiential products, or life experiences. Second, we replicated previous studies showing that life experiences provide more hedonic well-being and subjective economic value than material items. Finally, our pattern of results supports H2: Experiential products provided (a) similar levels of well-being compared to life experiences and (b) more well-being than material items.

Study 1 had one major limitation. The quasi-experimental design, which was necessary to determine how frequent experiential products were recalled, may have introduced self-selection bias. Although we controlled for trait-level happiness and financial security, other unmeasured differences between those who decided to write about one of the purchase types may have affected the evaluations of their purchases. Therefore, in Study 2, we used an experimental design in order to replicate support for $\mathrm{H} 2$.

\section{Study 2: Replicating the results of Study 1 with an experiment}

Because of our concern over self-selection bias in Study 1, the major goal of Study 2 was to replicate the results of Study 1 with an experiment. We randomly assigned people to reflect on a recently-purchased material item, experiential product, or life experience.

\section{Method}

\section{Participants}

A total of 194 people were recruited from Amazon's Mechanical Turk to complete our experiment in exchange for $\$ 0.25$. After removing those individuals who did not properly follow the instructions (see instruction checks below), 148 participants $\left(M_{\mathrm{age}}=29.70\right.$ years, $S D=11.68$ years; $63.5 \%$ female; $68.7 \%$ Caucasian) were used to test the support for $\mathrm{H} 2$.

\section{Materials and procedures}

We randomly assigned participants to think about a recent purchase that they would categorize as either purely material, equally material/experiential, or purely experiential. Then they wrote about the last time they "spent at least $\$ 10$ (but no more than \$10,000) of [their] own money on something they would categorize as [a/an purely material, equally material/experiential, or purely experiential] purchase." Next, they rated their purchase on hedonic well-being and subjective economic value. After completing their ratings, participants coded their purchase into one of 20 common purchase categories such as clothing, electronic device, or dining experience. Finally, they rated the extent to which their purchase was material or experiential (which served as our first instruction check; a total of 31 people were dropped because their material-experiential rating did not match their assigned condition), reported the cost of the purchase (which served as our second instruction check; a total of 3 people were dropped because their purchase was not within the instructed range of $\$ 10-\$ 10,000)$, and indicated when the purchase was made (which served as our third instruction check; a total of 12 people were dropped because their purchase was not within the instructed range of 1 year or less).

Hedonic well-being. In order to reliably measure how much their purchase provided hedonic well-being, participants answered three questions: "How much does this purchase contribute to your happiness today?," How much has this purchase contributed to your overall life's happiness?," and "How much do you think this purchase increased your overall life satisfaction?" on 7-point Likert scales, ranging from 1 (not at all) to 7 (very much). These three items were reliable $(\alpha=$ .87 ) and were averaged to measure hedonic well-being. Higher scores indicated the purchase contributed more happiness $(M=4.91, S D=1.41)$.

Subjective economic value. In order to reliably measure the subjective economic value of their purchases, participants answered three questions. In addition to the two questions from Study 1, participants answered "To what extent do you regret making this purchase?" from 1 (not at all) to 7 (very much; reverse coded). These three items were reliable $(\alpha=.79)$ and were averaged to measure subjective economic value. Higher 
scores indicated the purchase was perceived as a better financial investment $(M=5.74, S D=1.24)$.

\section{Preliminary analyses}

First, price significantly differed across purchase types $(F[2,143]=4.37, p=.01)$. Participants reflected on significantly more expensive experiential products compared to life experiences $(t[143]=2.66, p=.03)$ and material items $(t[143]=2.53$, $p=.02)$; however, there was no significant difference in the cost of life experiences compared to material items $(t[143]=.14$, $p=.99)$. There were no significant differences in the recency of purchases $(F[2,143]=.90, p=.41)$. However, to be consistent with Study 1, we controlled for both price and recency in our analyses. Therefore, following our established analytic plan, we conducted two one-way ANCOVAs (purchase type: material item vs. experiential product vs. life experience), controlling for both price and recency, to determine if the three purchases differed in well-being. For all pairwise $t$-tests we applied a Sidak adjustment (see Table 2 for significant differences in the covariate adjusted means).

\section{Well-being differences across purchase types}

The first one-way ANCOVA, controlling for price $(F[1,141]=.31, p=.57)$ and recency $(F[1,141]=.40$, $p=.53)$, demonstrated that there were significant differences on hedonic well-being $(F[2,141]=13.27, p<.001)$ that replicated the results from Study 1 and supported H2. Specifically, the three post-hoc pairwise $t$-tests confirmed that (a) life experiences provided more hedonic well-being than material items $(t[141]=3.31, p=.01, d=.65)$, (b) experiential products provided more hedonic well-being than material items $(t[141]=5.02, p<.001, d=1.06)$, and (c) experiential products and life experiences provided similar levels of hedonic well-being $(t[141]=1.93, p=.16, d=.41)$. A second one-way ANCOVA, controlling for price $F[1,141]=.49$, $p=.49)$ and recency $(F[1,141]=1.86, p=.18)$, demonstrated that there were significant differences on subjective economic value $(F[2,141]=5.96, p=.01)$ that also replicated the results from Study 1 and supported H2. Specifically, the three post-hoc pairwise $t$-tests confirmed that (a) life experiences provided more subjective economic value than material items $(t[141]=2.40, p=.05, d=.48)$, (b) experiential products provided more subjective economic value than material items, $(t[141]=3.30, p=.01, d=.70)$, and (c) experiential products and life experiences provided similar levels of subjective of economic value, $(t(141)=1.05, p=.64, d=.22)$.

\section{Brief discussion}

Study 2 provided experimental support for $\mathrm{H} 2$ : Experiential products provided similar levels of well-being compared to life experiences and more than material items. However, our experiments had a few limitations. First, the valence of the participants' purchases provides a possible alternative explanation for our results. Perhaps consumers are more likely to remember life experiences and experiential products that turned out well, and more likely to remember material items that turned out poorly. This difference in valence might have caused the differences in well-being. Second, even though we controlled for price, participants reflected on experiential products that were more expensive than life experiences. Third, demand effects could have impacted the results as participants were asked to rate both their happiness and subjective economic value from the purchase and then rate the purchase on a material-experiential continuum. Thus, we conducted Study 3 to eliminate these limitations. The second major goal of Study 3 was to test support for H4: The impact of purchase types on well-being can be explained by the satisfaction of psychological needs. In other words, we expect differences in psychological need satisfaction to explain why experiential products (a) provide more well-being than material items and (b) provide similar levels of well-being as life experiences.

\section{Study 3: Determining the impact purchases have on psychological need satisfaction}

Study 3 was conducted to (a) rule out a number of alternative explanations and (b) test support for both $\mathrm{H} 2$ and H4. To accomplish these goals, we randomly assigned participants to reflect on a positively- or negatively valenced material item, experiential product, or life experience. To reduce the effect of price, we restricted the purchase cost to be between \$25 and \$1000. To reduce demand characteristics, we counterbalanced the presentation of the well-being and material-experiential ratings. Finally, participants rated the degree to which their purchase provided hedonic well-being and subjective economic value (replicating Study 2) as well as how much their purchase satisfied their needs for identity (a consumer proxy for autonomy), competence, and relatedness (testing H4).

\section{Method}

\section{Participants}

A total of 695 people were recruited from Amazon's Mechanical Turk to complete our experiment in exchange for $\$ 0.50$. After removing those individuals who did not properly follow the instructions (see instruction checks below), 461 participants $\left(M_{\text {age }}=33.92, S D=12.38\right.$ years; $53.9 \%$ female; $81.1 \%$ Caucasian) were used to test the support for $\mathrm{H} 2$ and $\mathrm{H} 4$.

\section{Materials and procedures}

We randomly assigned participants to think about a recent purchase that they would categorize as either purely material, equally material/experiential, or purely experiential that either did or did not turn out well. Participants read similar instructions from Study 2 with a few slight modifications. First, participants were instructed to "think of the last time you bought a (purely material, equally material and experiential, or purely experiential) purchase" that (a) "turned out well and you enjoyed the purchase" or (b) "did not turn out well and you did not enjoy the purchase" (similar to Nicolao et al., 2009 instructions). Second, to reduce temporal differences in 
consumption and ensure they were reflecting on the consumption of their purchase, we asked participants to write about either (a) the last time they used this material purchase/equally material and experiential purchase or (b) when they lived through this primarily experiential purchase. Finally, the instructions differed slightly in presentation to about half the participants (e.g., using boldface or lightface type); however, this did not moderate any of the main effects or interactions, and thus, we report the results for the total sample.

Participants then rated the extent to which they considered their purchase to be material or experiential (this served as our first instruction check; a total of 85 people were dropped because their material-experiential rating did not match their assigned condition) and the degree to which the purchase contributed to hedonic well-being and subjective economic value (with these experiential ratings and well-being questions counterbalanced to reduce demand characteristics; there was no support for an order effect). They then rated the degree to which their purchase satisfied their needs for identity, competence, and relatedness. Finally, they reported the price (which served as our second instruction check; a total of 52 people were dropped because their purchase was not within the instructed range of $\$ 25-\$ 1,000$ ), when the purchase was made (which served as our third instruction check; a total of 12 people were dropped because their purchase was not within the instructed range of 1 year or less), and if the purchase turned out well or not (which served as our fourth instruction check; a total of 43 people were dropped because their valence rating did not match their assigned condition).

Hedonic well-being and subjective economic value. We used the same items from Study 2 to measure hedonic well-being and subjective economic value. The items were reliable for hedonic well-being $(\alpha=.94)$ and subjective economic value $(\alpha=.94)$.

Identity. Similar to previous studies (see Pchelin \& Howell, 2014; Zhang et al., 2014), we measured the extent the purchase expressed a person's identity or "true self" as a proxy for the need for autonomy. Participants answered three questions (e.g., "To what extent did this purchase reflect your true identity?)" from a 1 (not at all) to 7 (very much). These items were reliable $(\alpha=.91)$ and were averaged to measure identity expression. Higher scores indicated more expression of one's true self or identity.

Competence. To measure the extent to which the purchase allowed the person to use their talents or abilities, participants answered three questions (e.g., "To what extent did this purchase allow you to utilize a skill?") from a 1 (not at all) to 7 (very much). These items were reliable $(\alpha=.76)$ and were averaged to measure competence satisfaction. Higher scores indicated more competence satisfaction.

Relatedness. To measure the extent to which the purchase helped develop supportive relationships, participants answered three questions (e.g., "How much did this purchase allow you to relate to others in a meaningful way?") from 1 (not at all) to 7 (very much). These items were reliable $(\alpha=.86)$ and were averaged to measure relatedness satisfaction. Higher scores indicated more relatedness satisfaction.

\section{Results}

\section{Preliminary analyses}

First, price significantly differed across the three purchase types $(F[2,455]=3.20, p=.04)$ as well as across the two valence conditions $(F[1,455]=8.04, p=.01)$; however, there was not a significant interaction $(F[2,455]=.45, p=.64)$. Participants reflected on significantly more expensive experiential products than material items $(t[455]=2.53, p=.04)$; however, there was no significant difference in the cost of life experiences and material items $(t[455]=1.33, p=.45)$ nor the cost of life experiences and experiential products $(t[455]=1.10$, $p=.61)$. Additionally, participants in the positively valenced condition recalled more expensive purchases than participants in the negatively valenced condition $(t[455]=2.83, p=.01)$. Second, the recency of the purchase also significantly differed across the three purchase types $(F[2,455]=25.87, p<.001)$ as well as across the two valence conditions $(F[1,455]=43.86$, $p<.001)$; again, there was not a significant interaction $(F$ $[2,455]=1.41, p=.25)$. Life experiences were older than experiential products $(t[455]=6.13, p<.001)$ and material items $(t[455]=6.32, p<.001)$; however, there was no significant difference in recency comparing experiential products and material items $(t[455]=.40, p=.97)$. Additionally, participants in the positively valenced condition recalled more recent purchases than participants in the negatively valenced condition $(t[455]=6.63, p<.001)$.

Therefore, following our established analytic plan, we conducted five 2 (purchase valence: positive vs. negative) X 3 (purchase type: material item vs. experiential product vs. life experience) factorial ANCOVAs, controlling for price and recency, to determine if the three purchases differed in hedonic well-being, subjective economic value, and the psychological needs of identity, competence, and relatedness. When there was a significant purchase type by valence interaction, we examined the differences in well-being or psychological need satisfaction across the three purchase types independently within the two valence conditions. For all pairwise $t$-tests we applied a Sidak adjustment (see Table 3 for the significant covariate adjusted means reported separately by valence condition).

\section{Well-being differences across three purchase types}

Hedonic well-being. The first two-way ANCOVA, controlling for price $(F[1,453]=8.40, p=.01)$ and recency $(F[1,453]=4.55, p=.03)$, demonstrated that there were significant differences in hedonic well-being across the three purchase types $(F[2,453]=10.20, p<.001)$ and across the valence condition $(F[1,453]=948.41, p<.001)$; moreover, there was a significant purchase type by valence interaction $(F[2,453]=4.90, p=.01)$. For positively valenced purchases 
Table 3

Study 3: Covariate adjusted means and standard errors for purchase benefits across three purchase types separately by valence.

\begin{tabular}{|c|c|c|c|c|c|c|}
\hline \multirow[b]{3}{*}{ Purchase outcomes } & \multicolumn{6}{|c|}{ Purchase type } \\
\hline & \multicolumn{2}{|c|}{$\begin{array}{l}\text { Material } \\
\text { product }\end{array}$} & \multicolumn{2}{|c|}{$\begin{array}{l}\text { Experiential } \\
\text { product }\end{array}$} & \multicolumn{2}{|c|}{$\begin{array}{l}\text { Life } \\
\text { experience }\end{array}$} \\
\hline & $M$ & $S E$ & $M$ & $S E$ & $M$ & $S E$ \\
\hline \multicolumn{7}{|l|}{ Purchase turned out well } \\
\hline $\begin{array}{l}\text { Hedonic well-being } \\
\qquad(F[2,453]=11.25, p<.001)\end{array}$ & $4.80^{\mathrm{b}}$ & .12 & $5.50^{\mathrm{a}}$ & .11 & $5.46^{\mathrm{a}}$ & .12 \\
\hline $\begin{array}{l}\text { Subjective economic value } \\
\quad(F[2,452]=3.88, p=.02)\end{array}$ & $5.76^{\mathrm{b}}$ & .11 & $6.09^{\mathrm{a}}$ & .10 & $6.13^{\mathrm{a}}$ & .11 \\
\hline $\begin{array}{l}\text { Identity satisfaction } \\
\qquad(F[2,453]=13.63, p<.001)\end{array}$ & $3.84^{\mathrm{b}}$ & .17 & $4.71^{\mathrm{a}}$ & .15 & $5.10^{\mathrm{a}}$ & .17 \\
\hline $\begin{array}{l}\text { Competence satisfaction } \\
\qquad(F[2,453]=29.49, p<.001)\end{array}$ & $3.23^{\mathrm{c}}$ & .18 & $4.78^{\mathrm{a}}$ & .14 & $4.09^{\mathrm{b}}$ & .17 \\
\hline $\begin{array}{l}\text { Relatedness satisfaction } \\
\qquad(F[2,453]=44.51, p<.001)\end{array}$ & $2.60^{\mathrm{c}}$ & .19 & $4.07^{\mathrm{b}}$ & .15 & $4.72^{\mathrm{a}}$ & .17 \\
\hline \multicolumn{7}{|l|}{ Purchase turned out poorly } \\
\hline $\begin{array}{l}\text { Hedonic well-being } \\
\qquad(F[2,453]=4.92, p=.01)\end{array}$ & $1.74^{\mathrm{a}, \mathrm{b}}$ & .14 & $2.18^{\mathrm{a}}$ & .14 & $1.58^{\mathrm{b}}$ & .12 \\
\hline $\begin{array}{l}\text { Subjective economic value } \\
\qquad(F[2,452]=2.37, p=.10)\end{array}$ & $1.95^{\mathrm{a}}$ & .13 & $2.17^{\mathrm{a}}$ & .12 & $1.80^{\mathrm{a}}$ & .11 \\
\hline $\begin{array}{l}\text { Identity satisfaction } \\
\qquad(F[2,453]=2.42, p=.09)\end{array}$ & $2.42^{\mathrm{a}}$ & .20 & $3.01^{\mathrm{a}}$ & .18 & $2.74^{\mathrm{a}}$ & .21 \\
\hline $\begin{array}{l}\text { Competence satisfaction } \\
\qquad(F[2,453]=9.67, p<.001)\end{array}$ & $2.30^{\mathrm{b}}$ & .18 & $3.23^{\mathrm{a}}$ & .17 & $2.29^{\mathrm{b}}$ & .21 \\
\hline $\begin{array}{l}\text { Relatedness satisfaction } \\
\quad(F[2,453]=8.78, p<.001)\end{array}$ & $1.65^{\mathrm{b}}$ & .19 & $2.23^{\mathrm{a}, \mathrm{b}}$ & .18 & $2.82^{\mathrm{a}}$ & .21 \\
\hline
\end{tabular}

Note. For all outcomes we report omnibus results as well as which pair of covariate adjusted means differ within each study. Superscripts denote significant differences between purchase types at $p \leq .05$ after applying a Sidak adjustment. All means are adjusted for price and recency of purchase.

(i.e., those that turned out well), (a) life experiences provided more hedonic well-being than material items $(t[453]=3.79$, $p<.001, d=.59$ ), (b) experiential products provided more hedonic well-being than material items $(t \quad[453]=4.34$, $p<.001, d=.63$ ), and (c) experiential products and life experiences provided similar levels of hedonic well-being, $(t[453]=.23, p=.99, d=.03)$. These results replicate our findings in Study 1 and Study 2 and support H2. For negatively valenced purchases (i.e., those that did not turn out well), (a) life experiences and material items provided the same hedonic well-being $(t \quad[453]=.74, \quad p=.84, \quad d=.13)$, (b) experiential products provided marginally more hedonic well-being than material items $(t[453]=2.26, p=.07, d=.41)$, and (c) experiential products provided more hedonic well-being than life experiences $(t[453]=2.96, p=.01, d=.54)$.

Subjective economic value. The second two-way ANCOVA, controlling for price $(F[1,452]=.72, p=.38)$ and recency $(F$ $[1,452]=1.90, p=.16)$, demonstrated that there were significant differences on subjective economic value across the three purchase types $(F[2,452]=3.20, p=.04)$ and across the valence condition $(F[1,452]=1667.76, p<.001)$; moreover, there was a marginally significant purchase type by valence interaction $(F[2,452]=2.86, p=.06)$. For positively valenced purchases, (a) life experiences provided more subjective economic value than material items $(t[452]=2.44, p=.04$, $d=.38$ ), (b) experiential products provided more subjective economic value than material items $(t[452]=2.39, p=.05$, $d=.34$ ), and (c) experiential products and life experiences provided similar levels of subjective economic value $(t[452]=.27$, $p=.99, d=.04)$. These results replicate our findings in Study 1 and Study 2 and support H2. For negatively valenced purchases, (a) life experiences and material items provided the same subjective economic value $(t[452]=.85, p=.78, d=.15)$, (b) experiential products and material items provided the same subjective economic value $(t[452]=1.30, p=.48, d=.22)$, and (c) experiential products provided marginally more subjective economic value than life experiences $(t[453]=2.14$, $p=.10, d=.39$ ).

\section{Psychological need satisfaction differences across three purchase types}

Identity. The third two-way ANCOVA, controlling for price $(F[1,453]=7.81, p=.01)$ and recency $(F[1,453]=6.01$, $p=.02)$, demonstrated that there were significant differences on identity expression across the three purchase types $(F[2,453]=11.06, p<.001)$ and across the valence condition $(F[1,453]=138.27, p<.001)$; moreover, there was a marginally significant purchase type by valence interaction $(F[2,453]=2.84, p=.06)$. For positively valenced purchases, (a) life experiences provided more identity expression than material items $(t[453]=4.94, p<.001, d=.78)$, (b) experiential products provided more identity expression than material items $(t[453]=3.95, p<.001, d=.57)$, and (c) experiential products and life experiences provided similar levels of identity expression $(t[453]=1.32, p=.46, d=.20)$. For negatively valenced purchases, (a) life experiences and material items provided similar levels of identity expression $(t[452]=1.12, p=.60, d=.20)$, (b) experiential products provided marginally more identity expression than material items $(t[452]=2.20, p=.08, d=.38)$, and (c) experiential products and life experiences provided similar levels of identity expression $(t[453]=.98, p=.70, d=.18)$.

Competence. The fourth two-way ANCOVA, controlling for price $(F[1,453]=46.45, p<.001)$ and recency $(F[1,452]=.35$, $p=.67)$, demonstrated that there were significant differences in competence satisfaction across the three purchase types $(F[2,453]=31.59, p<.001)$ and across the valence condition $(F[1,453]=103.74, p<.001)$; moreover, there was a significant purchase type by valence interaction $(F[2,453]=3.55$, $p=.03$ ). For positively valenced purchases, (a) life experiences provided more competence satisfaction than material items $(t[453]=3.88, p<.001, d=.61)$, (b) experiential products provided more competence satisfaction than material items $(t[453]=7.69, p<.001, d=1.12)$, and (c) experiential products provided more competence satisfaction than life experiences $(t[453]=3.13, p=.01, d=.51)$. For negatively valenced purchases, (a) life experiences and material items provided similar levels of competence satisfaction $(t$ [453] $=$ $.02, p=.99, d=.001$ ), (b) experiential products provided more competence satisfaction than material items, $(t[453]=$ 
$3.79, p=.01, d=.68$ ), and (c) experiential products provided more competence satisfaction than life experiences $(t[453]=$ $3.70, p=.01, d=.68)$.

Relatedness. The final two-way ANCOVA, controlling for price $(F[1,453]=6.93, p=.01)$ and recency $(F[1,453]=.79$, $p=.37)$, demonstrated that there were significant differences on relatedness satisfaction across the three purchase types $(F[2,453]=40.78, p<.001)$ and across the valence condition $(F[1,453]=106.90, p<.001)$; moreover, there was a significant purchase type by valence interaction $(F[2,453]=4.47, p=.01)$. For positively valenced purchases, (a) life experiences provided more relatedness satisfaction than material items $(t[453]=9.07$, $p<.001, d=1.42$ ), (b) experiential products provided more relatedness satisfaction than material items $(t[453]=6.76$, $p<.001, d=.99)$, and (c) experiential products provided less relatedness satisfaction than life experiences $(t[453]=2.89$, $p=.01, d=.44$ ). For negatively valenced purchases, (a) life experiences provided more relatedness satisfaction than material items $(t[453]=4.18, p=<.001, d=.79)$, (b) experiential products provided marginally more relatedness satisfaction than material items $(t[453]=2.23, p=.08, d=.39)$, and (c) experiential products provided marginally less relatedness satisfaction than life experiences $(t[453]=2.15, p=.09$, $d=.39$ ).

\section{Testing the support for $\mathrm{H} 4$}

The pattern of means from the previous three analyses suggests why there is consistent support for H2. First, experiential products, compared to material items, better satisfy the psychological needs of autonomy (measured as identity expression), competence, and relatedness. Second, and more provocatively, the support for $\mathrm{H} 2$ may be a result of two opposite suppression effects. Specifically, because experiential products better satisfy the need for competence while life experiences better satisfy the need for relatedness, two opposite-signed indirect paths may be suppressing any mean difference in well-being when comparing life experiences and experiential products. Our final two analyses test both of these explanations.

To determine if the increase in hedonic well-being from experiential products, compared to material items, is mediated by psychological need satisfaction when controlling for purchase price, recency and valence, we used the Hayes PROCESS macro to conduct mediation analyses (Model 4; see Hayes, 2013). Additionally, we estimated the bias-corrected coefficients from a series of 5,000 bootstrap samples (see Preacher, Rucker, \& Hayes, 2007). As predicted by H4, this model supported mediation (see Fig. 1) by demonstrating that (a) experiential products were associated with increased hedonic well-being $(\beta=.18, t=3.00, p<.01)$, (b) experiential products were associated with increased identity $(\beta=.24$, $t=4.13, p<.01)$, competence $(\beta=.41, t=7.65, p<.01)$, and relatedness $(\beta=.34, t=5.99, p<.01)$ satisfaction, (c) increased identity $(\beta=.37, t=4.96, p<.01)$, competence $(\beta=.24, t=3.18, p<.01)$, and relatedness $(\beta=.17, t=2.91$, $p<.01)$ satisfaction were all uniquely associated with increased hedonic well-being, and (d) there was not a significant direct path after entering the mediators into the model $(\beta=-.06, t=1.09, p=.28)$. Importantly, the indirect effects through identity, competence, and relatedness satisfaction were all significant $(Z=3.13, Z=2.91, Z=2.59$, respectively). Thus, this model supports H4: The impact of experiential products on well-being, compared to material items, can be explained by the satisfaction of psychological needs.

To determine if the similarity in hedonic well-being for experiential products and life experiences was the result of the two purchases satisfying different psychological needs (i.e., competence and relatedness) we used the Hayes PROCESS macro to examine these indirect paths (Model 4; see Hayes, 2013). Support for dual suppression would be accepted if (a) the indirect paths through competence and relatedness satisfaction were significant but in opposite directions; (b) when life experiences satisfied the need for competence as well as experiential products, the model would show a direct effect

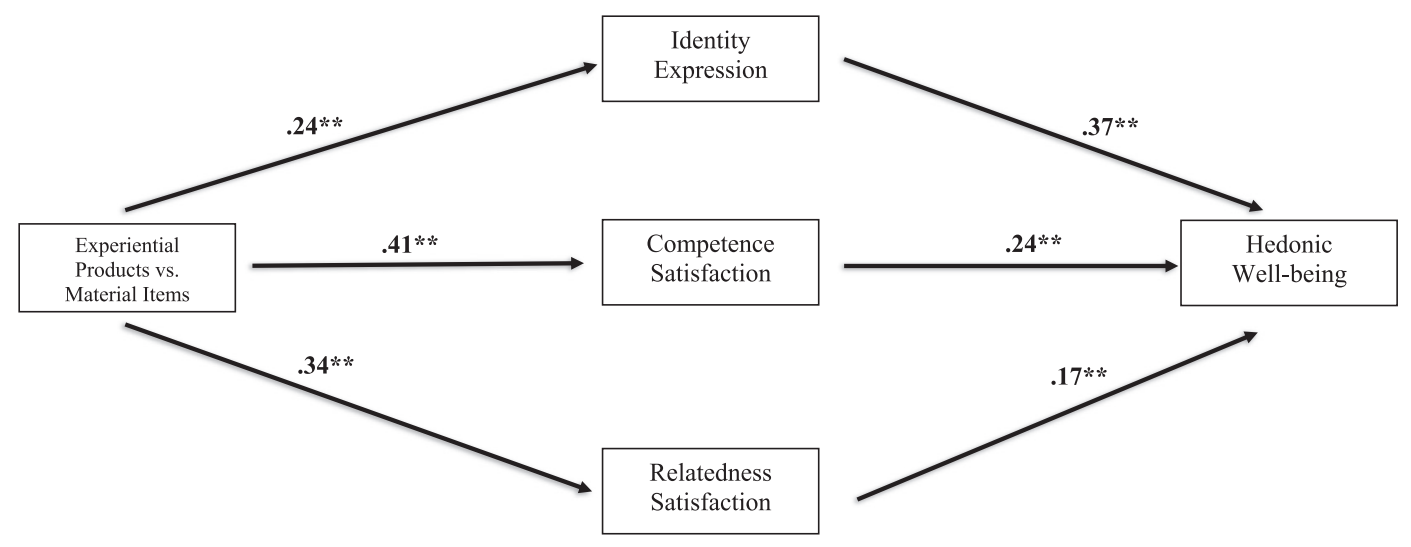

Fig. 1. As predicted by H4, (a) experiential products, compared to material items, were associated with increased hedonic well-being ( $\beta=.18)$, (b) experiential products were associated with increased identity, competence, and relatedness satisfaction, (c) increased identity, competence, and relatedness satisfaction were all uniquely associated with increased hedonic well-being, and (d) there was not a significant direct path after entering the mediators into the model $(\beta=-.06)$. Importantly, the indirect effects through identity, competence, and relatedness satisfaction were all significant $(Z=3.13, Z=2.91, Z=2.59$, respectively). 
with life experiences leading to more hedonic well-being; and (c) when experiential products satisfied the need for relatedness as well as life experiences, the model would show a direct effect with experiential products leading to more hedonic well-being. All three of these criteria were met (see Fig. 2). First, although experiential products and life experiences provided the same identity satisfaction $(\beta=.03, t=.56, p=.57)$, experiential products provided more competence satisfaction $(\beta=.25, t=4.63, p<.01)$ and less relatedness satisfaction $(\beta=-.14, t=2.52, p<.01)$. Second, the indirect paths through competence and relatedness were significant and in opposite directions $(Z=2.50, Z=-2.16$, respectively). Finally, the model predicts that (a) when experiential products provide the same relatedness satisfaction as life experiences, they provide more hedonic well-being (total effect $=.20, \mathrm{SE}=.10$, $p=.04$ ) and (b) when life experiences provide the same competence satisfaction as experiential products, they provide more hedonic well-being (total effect $=.27, \mathrm{SE}=.10, p=.01$ ).

\section{General discussion}

Our studies help address the gap in the material-experiential buying literature regarding the effects of experiential products on well-being and provide more evidence for the refinement of the experience recommendation. First, the mean well-being levels from Study 1, Study 2, and the positively valenced purchases in Study 3 showed a consistent pattern: (a) life experiences provided more well-being than material items (replicating the typical effect in the material-experiential buying literature), (b) experiential products provided more well-being than material items, and (c) experiential products and life experiences provided similar levels of well-being. Thus, these results are consistent with H2: Experiential products provide similar levels of well-being compared to life experiences and more than material items.

Additionally, our mediation model in Study 3 demonstrated that, much like life experiences (see Caprariello \& Reis, 2013; Carter \& Gilovich, 2012; Howell \& Hill, 2009), experiential products, compared to material items, result in more hedonic well-being because they better satisfy the psychological needs of autonomy, competence, and relatedness. The results of Study 3 also help explain why experiential products and life experiences provide similar levels of well-being in Studies 1, 2 , and 3 - by satisfying different psychological needs. Although experiential products and life experiences satisfy identity expression equally well, experiential products provide more competence satisfaction while life experiences provide more relatedness satisfaction. Thus, experiential products and life experiences likely provide similar levels of well-being in all three studies because they satisfy different psychological needs. Importantly, both models support $\mathrm{H} 4$ : The relationship between purchase type and well-being are explained through the satisfaction of psychological needs.

\section{Why do experiential products better satisfy psychological needs than material items?}

Given that material items and experiential products are both tangible goods, our results demonstrate that the tangibility of a product does not necessarily undermine the well-being it can provide. Therefore, we propose a few characteristics of experiential products which may allow them to better satisfy psychological needs than material items in spite of their shared tangible nature. We begin by examining the most commonly recalled experiential products in Studies 1, 2, and 3: electronic devices, video games, and sporting goods (see Table 1). Inspecting the specific categories, we find that these purchases include products such as laptops, computers, video games, and sporting goods which require the consumer to utilize certain skills and abilities; they may also be purchased with the intention to be shared with others. In comparison, material items were mostly clothing, jewelry, and accessories; these purchases tend to be an end in themselves and are greatly affected by extrinsic concerns and goals (Csikszentmihalyi \& Rochberg-Halton, 1981; Fournier \& Richins, 1991; Van Boven \& Gilovich, 2003).

Experiential products like video games often challenge people by using problem-solving scenarios and requiring

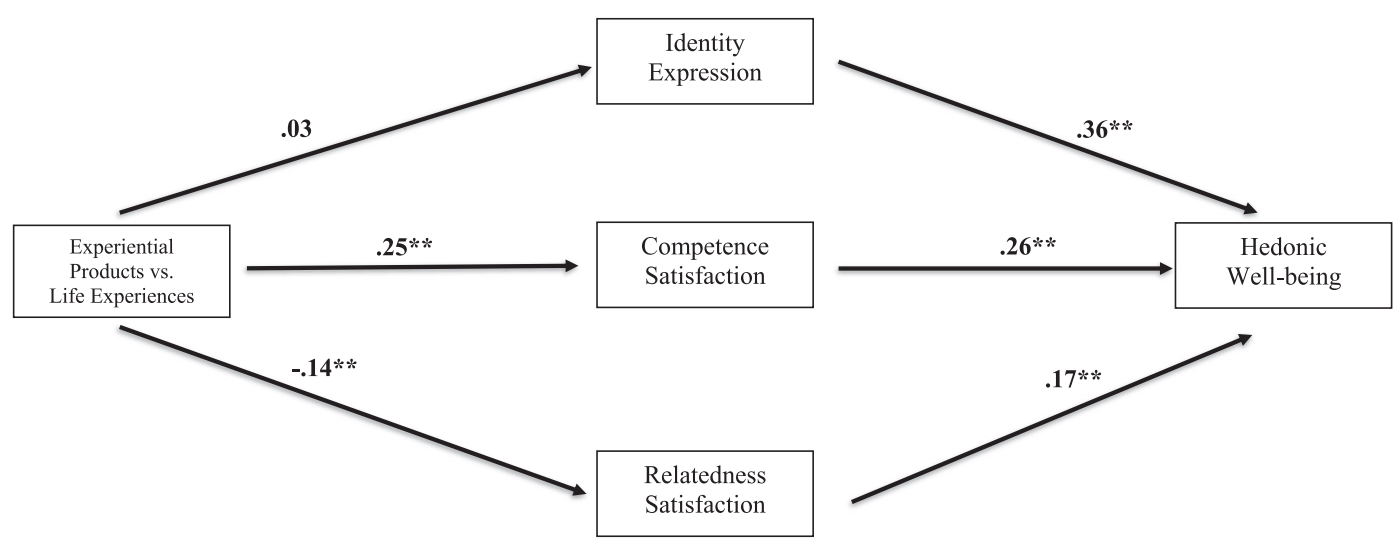

Fig. 2. Supporting dual suppression, although experiential products and life experiences provided the same identity satisfaction, experiential products provided more competence satisfaction and less relatedness satisfaction compared to life experiences. Also, the indirect paths through competence and relatedness were significant and in opposite directions $(Z=2.50, Z=-2.16$, respectively). 
flexibility in thinking and hand-to-eye coordination. Moreover, video games and sporting goods are often purchased with the intention to be consumed with others. As described by Caprariello and Reis (2013), these social material purchases provide the same amount of well-being as do social life experiences because they both likely meet the need for relatedness. Given that people are more concerned with extrinsic, instead of intrinsic, factors when buying and consuming material items (Howell \& Hill, 2009; Zhang et al., 2013), and that experiential products better satisfy psychological needs than material items, it might be that consumers are less concerned with value-seeking, social comparison, or extrinsic goals when buying and consuming experiential products. A goal for future research is to determine the concern consumers have with extrinsic factors, compared to intrinsic ones, when buying and consuming experiential products and how it impacts well-being.

Why do life experiences and experiential products satisfy different psychological needs?

The results from Study 3 suggest that, regardless of the purchase valence, experiential products satisfy the psychological need for competence more than life experiences and that life experiences satisfy the psychological need for relatedness more than experiential products. These two opposite indirect paths appear to explain why life experiences and experiential products provide similar levels of well-being. The next question is: why do life experiences and experiential products satisfy different psychological needs? Using the marketing framework developed by Hirschman and Holbrook (1982, 1986) and extended by others (e.g., Gentile et al., 2007; Schmitt, 1999, 2010; Schmitt \& Zarantonello, 2013), the answer is likely connected to the type of consumer experience each purchase type facilitates. For example, video games and sporting goods promote the consumer experience dimension of pragmatic/thinking (Schmitt \& Zarantonello, 2013) which in turn facilitates the usage of skills and abilities that leads to more competence satisfaction (Deci \& Ryan, 2012). In contrast, life experiences such as dining out, fees and admissions, and traveling promote the consumer experience dimension of relations that focuses on enhancing social relationships (Schmitt \& Zarantonello, 2013), which in turn satisfies the psychological need for relatedness (Caprariello \& Reis, 2013).

Interestingly, it might be that experiential products, although likely more social than material items, are consumed alone more often than life experiences. Additionally, although electronic devices may involve others, individuals may not meet their relatedness needs, when compared to life experiences, because their attention is not as focused on the people they are interacting with. Moreover, the quality of connection an experiential product and a life experience provides may differ. More specifically, a laptop or tablet may help connect people with each other through social media or other communication outlets, but the quality of communication may satisfy relatedness needs less than other life experiences. A goal for future research is to determine how frequently experiential products are consumed with others and why experiential products and life experiences differ in the relatedness they provide.

\section{Limitation and future directions}

Although our results replicate across three studies, it is important to discuss limitations that future research could address. One limitation that has received little attention in the material-experiential buying literature is whether comparing material items and life experiences is ultimately unfair. One could argue that this comparison is a classic case of comparing apples and oranges because products and services differ on many dimensions such as tangibility, interactivity, extension of time, frequency of purchase, and a host of other factors (Hellén \& Gummerus, 2013). Although using these purchase types allow us to connect our work to prior research, we also believe that the comparison itself is not between the specific purchases but in the memory of the "consumption experience" that is facilitated by the purchase, be it a material item, experiential product, or life experience (Arnould, Price, \& Zinkhan, 2002; Carù \& Cova, 2003; Howell \& Guevarra, 2013). In this way, the comparison is among the memory of the consumption experience of each purchase type, and thus, we believe these consumption memories are comparable (Arnould et al., 2002).

However, without describing the different stages of the consumption experience to participants (i.e., every purchase takes place across a consumption timeline consisting of a pre-consumption experience, a purchase experience, a core consumption experience, and a remembered consumption experience), it is possible that some of the differences we observed were the result of participants focusing on different stages of the consumption experience (Arnould et al., 2002). We attempted to reduce this concern in Study 3 by asking participants to compare their memory of the core consumption experience by instructing them to reflect on the last time they "used" their material item or experiential product or "lived through" their life experience. Future research could better systematically examine how each purchase type differs across all four stages of the consumption experience. We think it is reasonable to believe that the three purchase types may differ drastically on well-being outcomes during the preconsumption, purchase, and core consumption experiences (Arnould et al., 2002; Carù \& Cova, 2003; Howell \& Guevarra, 2013). For example, although the current studies provide support for $\mathrm{H} 2$ during reflection (in this case the remembered consumption experience), given that the actual experience of pleasure (in this case the core consumption) is different from remembered pleasure (Fredrickson \& Kahneman, 1993), we do not know if the same well-being patterns occur in real time.

A second future direction that has already been undertaken in recent studies is determining the purchase (Bhattacharjee \& Mogilner, 2014; Caprariello \& Reis, 2013; Nicolao et al., 2009) and person (Hill \& Howell, 2014; Zhang et al., 2014) moderators of the experiential advantage. For example, the experiential advantage is moderated by the valence (Nicolao et al., 2009), socialness (Caprariello \& Reis, 2013), and 
extraordinariness (Bhattacharjee \& Mogilner, 2014) of the purchase as well as the habitual buying tendencies of the consumer (Howell, Pchelin, \& Iyer, 2012; Zhang et al., 2014). Zhang et al. (2014) found that those who are less likely to habitually buy life experiences, compared to those who are more likely to habitually buy them, are not as happy with their experiential purchases. All these moderators should be reexamined when including experiential products like we did in Study 3 testing the moderating effect of purchase valence. Our results replicated the purchase by valence interaction reported by Nicolao et al. (2009); i.e., only when purchases turned out well did life experiences make people happier than material items); moreover, we extended their results by showing that when purchases turn out poorly, experiential products provide the most hedonic well-being compared to both material items and life experiences. Furthermore, many of these moderators are important components of the Positive-Activity Model which posits that the well-being derived from an activity is a function of the fit between the person and the activity (Lyubomirsky \& Layous, 2013). Because the satisfaction of psychological needs explains the relationship between purchase types and well-being, as predicted by the Positive-Activity Model, future studies should examine the various person and activity moderators to determine which factors promote or impede the satisfaction of these psychological needs during consumption.

\section{Conclusion}

The results of our three studies simultaneously replicate and extend the support for the experience recommendation - both life experiences (supporting the experience recommendation) and experiential products (extending the experience recommendation) provide more well-being than material items. Moreover, these differences in well-being are mostly explained by the degree to which the purchase satisfies the psychological needs of autonomy, competence, and relatedness. Interestingly, experiential products satisfy the need for competence more than life experiences, and life experiences satisfy the need for relatedness more than experiential products. Thus, we add to several recent findings demonstrating that the experience recommendation is, as it stands, too simplistic, and that boundaries and caveats should be offered to consumers. Because people are faced with consumption decisions that provide opportunities for happiness, a more accurate view of how various expenditures impact well-being is imperative in order to help individuals optimize their spending decisions. Therefore, at the very least, we propose appending the experience recommendation: If you want to be happier, buy life experiences instead of material items; however, if you are going to buy material items, buy those that provide you with experiences.

\section{References}

Alba, J. W., \& Williams, E. F. (2012). Pleasure principles: A review of research on hedonic consumption. Journal of Consumer Psychology, 23(1), 2-18.

Andrade, E. B., \& Cohen, J. B. (2007). On the consumption of negative feelings. Journal of Consumer Research, 34(3), 283-300.
Arnould, E. J., \& Price, L. L. (1993). River magic: Extraordinary experience and the extended service encounter. Journal of Consumer Research, 20(1), $24-45$.

Arnould, E., Price, L., \& Zinkhan, G. (2002). Consumers. New York: McGrawHill.

Baumeister, R. F., \& Leary, M. R. (1995). The need to belong: Desire for interpersonal attachments as a fundamental human motivation. Psychological Bulletin, 117(3), 497-529.

Bhattacharjee, A., \& Mogilner, C. (2014). Happiness from ordinary and extraordinary experiences. Journal of Consumer Research, 41(1), 1-17.

Bigné, J. E., Mattila, A. S., \& Andreu, L. (2008). The impact of experiential consumption cognitions and emotions on behavioral intentions. Journal of Services Marketing, 22(4), 303-315.

Boehm, J. K., Lyubomirsky, S., \& Sheldon, K. M. (2011). A longitudinal experimental study comparing the effectiveness of happiness-enhancing strategies in Anglo Americans and Asian Americans. Cognition and Emotion, 25(7), 1263-1272.

Braun, K. A. (1999). Postexperience advertising effects on consumer memory. Journal of Consumer Research, 25(4), 319-334.

Burroughs, J. E., \& Rindfleisch, A. (2002). Materialism and well-being: A conflicting values perspective. Journal of Consumer Research, 29(3), 348-370.

Caprariello, P. A., \& Reis, H. T. (2013). To do, to have, or to share? Valuing experiences over material possessions depends on the involvement of others. Journal of Personality and Social Psychology, 104(2), 199-215.

Carmon, Z., Wertenbroch, K., \& Zeelenberg, M. (2003). Option attachment: When deliberating makes choosing feel like losing. Journal of Consumer Research, 30(1), 15-29.

Carter, T. J., \& Gilovich, T. (2010). The relative relativity of material and experiential purchases. Journal of Personality and Social Psychology, 98(1), 146-159.

Carter, T. J., \& Gilovich, T. (2012). I am what I do, not what I have: The differential centrality of experiential and material purchases to the self. Journal of Personality and Social Psychology, 102(6), 1304-1317.

Carter, T. J., \& Gilovich, T. (2014). Getting the most for the money: The hedonic return on experiential and material purchases. In M. Tatzel (Ed.), Consumption and well-being in the material world (pp. 49-62). New York: Springer.

Carù, A., \& Cova, B. (2003). Revisiting consumption experience a more humble but complete view of the concept. Marketing Theory, 3(2), $267-286$.

Celsi, R. L., Rose, R. L., \& Leigh, T. W. (1993). An exploration of high-risk leisure consumption through skydiving. Journal of Consumer Research, 20(1), 1-23.

Cotte, J. (1997). Chances, trances, and lots of slots: Gambling motives and consumption experiences. Journal of Leisure Research, 29(4), 380-406.

Csikszentmihalyi, M., \& Rochberg-Halton, E. (1981). The meaning of things: Domestic symbols and the self. New York, NY: Cambridge University Press.

Deci, E. L. (1975). Intrinsic motivation. New York: Plenum.

Deci, E. L., \& Ryan, R. M. (2012). Motivation, personality, and development within embedded social contexts: An overview of self-determination theory. In R. M. Ryan (Ed.), The Oxford handbook of human motivation (pp. 85-107). New York, NY: Oxford University Press.

Dhar, R., \& Wertenbroch, K. (2000). Consumer choice between hedonic and utilitarian goods. Journal of Marketing Research, 37(1), 60-71.

Dunn, E. W., Gilbert, D. T., \& Wilson, T. D. (2011). If money doesn't make you happy, then you probably aren't spending it right. Journal of Consumer Psychology, 21(2), 115-125.

Emmons, R. A., \& McCullough, M. E. (2003). Counting blessings versus burdens: An experimental investigation of gratitude and subjective well-being in daily life. Journal of Personality and Social Psychology, 84(2), 377-389.

Ferraro, R., Escalas, J. E., \& Bettman, J. R. (2011). Our possessions, our selves: Domains of self-worth and the possession-self link. Journal of Consumer Psychology, 21(2), 169-177.

Fournier, S., \& Richins, M. L. (1991). Some theoretical and popular notions concerning materialism. Journal of Social Behavior and Personality, 6, 403-414. 
Fredrickson, B. L., Cohn, M. A., Coffey, K. A., Pek, J., \& Finkel, S. M. (2008). Open hearts build lives: Positive emotions, induced through lovingkindness meditation, build consequential personal resources. Journal of Personality and Social Psychology, 95(5), 1045-1062.

Fredrickson, B. L., \& Kahneman, D. (1993). Duration neglect in retrospective evaluations of affective episodes. Journal of Personality and Social Psychology, 65(1), 45-55.

Gentile, C., Spiller, N., \& Noci, G. (2007). How to sustain the customer experience: An overview of experience components that co-create value with the customer. European Management Journal, 25(5), 395-410.

Grönroos, C. (2008). Service logic revisited: who creates value? And who cocreates? European Business Review, 20(4), 298-314.

Hayes, A. F. (2013). Introduction to mediation, moderation, and conditional process analysis. New York, NY: The Guilford Press.

Hellén, K., \& Gummerus, J. (2013). Re-investigating the nature of tangibility/ intangibility and its influence on consumer experiences. Journal of Service Management, 24(2), 130-150.

Hill, G., \& Howell, R. T. (2014). Moderators and mediators of pro-social spending and well-being: The influence of values and psychological need satisfaction. Personality and Individual Differences, 69, 69-74.

Hirschman, E. C., \& Holbrook, M. B. (1982). Consumption: Emerging concepts. Journal of Marketing, 46(3), 92-101.

Hirschman, E. C., \& Holbrook, M. B. (1986). Expanding the ontology and methodology of research on the consumption experience. In D. Brinberg, \& R. J. Lutz (Eds.), Perspectives on methodology in consumer research (pp. 213-251). New York, NY: Springer-Verlag.

Holbrook, M. B., \& Hirschman, E. C. (1982). The experiential aspects of consumption: Consumer fantasies, feelings, and fun. Journal of Consumer Research, 9(2), 132-140.

Howell, R. T., \& Guevarra, D. A. (2013). Buying happiness: Differential consumption experiences for material and experiential purchases. In A. M. Columbus (Ed.), Advances in psychology research. , Vol. 98. (pp. 57-69). Hauppauge, NY: Nova Science Publishers.

Howell, R. T., \& Hill, G. (2009). The mediators of experiential purchases: Determining the impact of psychological needs satisfaction and social comparison. The Journal of Positive Psychology, 4(6), 511-522.

Howell, R. T., \& Howell, C. J. (2008). The relation of economic status to subjective well-being in developing countries: A meta-analysis. Psychological Bulletin, 134(4), 536-560.

Howell, R. T., Pchelin, P., \& Iyer, R. (2012). The preference for experiences over possessions: Measurement and construct validation of the Experiential Buying Tendency Scale. The Journal of Positive Psychology, 7(1), $57-71$.

Hsee, C. K., Yang, Y., Li, N., \& Shen, L. (2009). Wealth, warmth, and wellbeing: Whether happiness is relative or absolute depends on whether it is about money, acquisition, or consumption. Journal of Marketing Research, 46(3), 396-409.

Lovelock, C., \& Gummesson, E. (2004). Whither services marketing? In search of a new paradigm and fresh perspectives. Journal of Service Research, $7(1), 20-41$.

Lynch, J. R., Alba, J. W., Krishna, A., Morwitz, V. G., \& Gürhan-Canli, Z. (2012). Knowledge creation in consumer research: Multiple routes, multiple criteria. Journal of Consumer Psychology, 22(4), 473-485.

Lyubomirsky, S., King, L., \& Diener, E. (2005). The benefits of frequent positive affect: Does happiness lead to success? Psychological Bulletin, 131(6), 803-855.

Lyubomirsky, S., \& Layous, K. (2013). How do simple positive activities increase well-being? Current Directions in Psychological Science, 22(1), $57-62$.
Lyubomirsky, S., Sheldon, K. M., \& Schkade, D. (2005). Pursuing happiness: The architecture of sustainable change. Review of General Psychology, 9(2), 111.

Martín-Ruiz, D., \& Rondán-Cataluña, F. J. (2008). The nature and consequences of price unfairness in services: A comparison to tangible goods. International Journal of Service Industry Management, 19(3), $325-352$.

Moeller, S., \& Wittkowski, K. (2010). The burdens of ownership: Reasons for preferring renting. Managing Service Quality, 20(2), 176-191.

Nicolao, L., Irwin, J. R., \& Goodman, J. K. (2009). Happiness for sale: Do experiential purchases make consumers happier than material purchases? Journal of Consumer Research, 36(2), 188-198.

Okada, E. M. (2005). Justification effects on consumer choice of hedonic and utilitarian goods. Journal of Marketing Research, 42(1), 43-53.

Pchelin, P., \& Howell, R. T. (2014). The hidden cost of value-seeking: People do not accurately forecast the economic benefits of experiential purchases. The Journal of Positive Psychology, 9(4), 322-334.

Preacher, K. J., Rucker, D. D., \& Hayes, A. F. (2007). Addressing moderated mediation hypotheses: Theory, methods, and prescriptions. Multivariate Behavioral Research, 42(1), 185-227.

Raghunathan, R., \& Corfman, K. (2006). Is happiness shared doubled and sadness shared halved? Social influence on enjoyment of hedonic experiences. Journal of Marketing Research, 43(3), 386-394.

Rosenzweig, E., \& Gilovich, T. (2012). Buyer's remorse or missed opportunity? Differential regrets for material and experiential purchases. Journal of Personality and Social Psychology, 102(2), 215-223.

Ryan, R. M., \& Deci, E. L. (2000). Self-determination theory and the facilitation of intrinsic motivation, social development, and well-being. American Psychologist, 55(1), 68-78.

Ryan, R. M., \& Deci, E. L. (2001). On happiness and human potentials: A review of research on hedonic and eudaimonic well-being. Annual Review of Psychology, 52(1), 141-166.

Sääksjärvi, M., \& Hellén, K. (2013). How designers and marketers can work together to support consumers' happiness. International Journal of Design, $7(3), 33-44$.

Schmitt, B. H. (1999). Experiential marketing. Journal of Marketing Management, 15(1-3), 53-67.

Schmitt, B. H. (2010). Experience marketing. Concepts, frameworks and consumer insights. Foundations and Trends in Marketing, 5(2), 55-112.

Schmitt, B. H., \& Zarantonello, L. (2013). Consumer experience and experiential marketing: A critical review. Review of Marketing Research, $10,25-61$.

Van Boven, L. (2005). Experientialism, materialism, and the pursuit of happiness. Review of General Psychology, 9(2), 132-142.

Van Boven, L., \& Gilovich, T. (2003). To do or to have? That is the question. Journal of Personality and Social Psychology, 85(6), 1193-1202.

Zhang, J. W., Howell, R. T., \& Caprariello, P. A. (2013). Buying life experiences for the "right" reasons: A validation of the Motivations for Experiential Buying Scale. Journal of Happiness Studies, 14(3), 817-842.

Zhang, J. W., Howell, R. T., Caprariello, P. A., \& Guevarra, D. A. (2014). Damned if they do, damned if they don't: Material buyers are not happier from material or experiential consumption. Journal of Research in Personality, 50, 71-83.

Zhang, S., \& Markman, A. B. (2001). Processing product unique features: Alignability and involvement in preference construction. Journal of Consumer Psychology, 11(1), 13-27.

Zhong, J. Y., \& Mitchell, V. W. (2010). A mechanism model of the effect of hedonic product consumption on well-being. Journal of Consumer Psychology, 20(2), 152-162. 